\title{
The Difference of Learning and Trusting Models on the Results of Learning Bullet Styles Ortodoks Junior High School Students
}

\author{
Pangihutan Butar-Butar \\ Department of Sport Education \\ Post Graduate School, State University of Medan \\ Medan, North Sumatera, Indonesia
}

\author{
Imran Akhmad \\ Department of Sport Education \\ Post Graduate School, State University of Medan \\ Medan, North Sumatera, Indonesia
}

\author{
Rahma Dewi \\ Department of Sport Education \\ Post Graduate School, State University of Medan \\ Medan, North Sumatera, Indonesia
}

\begin{abstract}
The purpose of this study was to determine the interaction between learning models and students' confidence in class VIII SMP. This research was conducted on eighth grade junior high school students. then the treatment location was at Bandar Setia Ujujng Private Middle School, Jl.Pengabdian No. 75 Bandar Setia, Percut Sei Tuan District, Deli Serdang Regency, with a sample of 30 students. This study uses a purposive sample treatment by level $2 \times 2$. Data collection techniques in this study use portfolio sheets to test the learning outcomes of orthodox style shot put and questionnaires to measure student confidence in learning. Data analysis techniques using two-way analysis of variance (ANAVA) and then proceed with the homogeneity test. The results of this study are (1) There is a difference between the snowball throwing learning model and the self-check learning model because $\mathrm{FO}(\mathrm{A})=1621.69>\mathrm{Ftab}=4.11$ then $\mathrm{HO}$ is rejected, the conclusion (1) there are differences in learning outcomes of shot put on orthodox style material between students who were treated using snowball throwing learning models and students who were treated using self-learning learning models, to the learning outcomes of shot put on orthodox style material, (2) There was no interaction between snowball throwing learning models and models self-study because the price is calculated Fo interaction $=0.02$ and $F$ table $=4.05$ shows that the function $F$ $<\mathrm{Ft}$, so there is a reason to accept $\mathrm{Ho}$. The conclusion is that there is no interaction between the two learning models with confidence in the learning outcomes of shot put on orthodox style material.
\end{abstract}

Keywords - Learning Model, Confidence, Bulletproof Learning Outcomes

\section{INTRODUCTION}

The quality of education, as one of the pillars of meaningful human resource development, is very important for national development. It can even be said that the future of the nation depends on the existence of quality education that takes place in the present. Quality education will only emerge from quality schools. Therefore, efforts to improve the quality of schools are the central point of efforts to create quality education for the creation of quality workforce as well. In other words, efforts to improve the quality of schools are actions that never stop, anytime, anywhere and under any conditions.

In physical education there are three aspects that become research material, namely: cognitive, affective and psychomotor aspects. According to [1] states that: In the curriculum the goal of physical education is to support the development of cognitive aspects, psychomotor aspects. But this really depends on how physical education teachers orient development in learning programs.

However, in the implementation of physical education learning in the learning process there are still shortcomings and improvements are needed, especially in the learning of shot put, including: (1) lack of teacher approaches to students in the learning process, (2) lack of evaluation of learning outcomes for students at the end of the activity, (3) lack of clarity about the target to be achieved in the learning process (4) lack of understanding of the teacher in the method or approach that will be used in the delivery of learning material.

This can be seen from the average value of completeness in physical education, sports and health that does not meet the KKM (Minimum Mastery Criteria), which is 75. Especially in class VIII-2, amounting to 30 . In the test results only 9 students completed the study while 21 students others are incomplete or an average score of $25 \%$ with a degree of completeness, while the level of incompleteness reaches $75 \%$,

From the results of interviews with students and physical education teachers, it was found that the cause of the students' difficulties in doing shot put material, was due to mistakes in how to hold bullets such as fingers less tightly together with thumbs on the side, so it could not resist lest the bullets easily shift, then the prefix throwing bullets, not attached to the shoulder, the body position is less upright sideways towards the throw sector. The position of the left foot is less straight forward, the position of the right foot with the knee is not bent, the position of the right shoulder is slightly lower than the left shoulder. Meanwhile, from the attitude of refusing 
bullets, without a stop must immediately be followed by the movement of refusing bullets. The course of the push or repulsion of the bullet is less straight one line.

While from the final attitude of refusing bullets, students do not make the jumping motion to swap the right foot forward. So it does not coincide with the landing of the right foot, the left foot is pulled backward as well as the left arm to maintain balance

For theory in the classroom the teacher applies conventional learning with the teaching style of lecture, while for practice in the field the physical education teacher uses the command teaching style.

To avoid this physical education teacher should make the application of snowball throwing teaching style and check it by yourself, so students do not feel bored to do and have high spirits, with that students can gradually overcome the difficulties in learning.

In the book [2] there are 3 types of bullet holding techniques, namely:

1. The fingers are somewhat tenuous. The little finger is bent next to the bullet, so it can help to hold it so that the bullet is not easily displaced from its place. To use this method the bullet repellent must have strong and long fingers

2. The fingers are rather tight, the thumb is on the side, the little finger is on the back of the bullet. The little finger besides serves to hold the bullet easy to move, also helps to press when the bullet was rejected.

3. For those whose hands are rather small and the fingers are short, can use this third method, namely the fingers as in the second but more tenuous way. Pinkie behind the bullet so that it can join reject the bullet, thumb to hold the slide to the side.

"The learning model is a conceptual framework that describes a systematic procedure in organizing learning experiences to achieve certain learning goals and serves as a guide for learning designers and instructors in planning teaching and learning activities" [3] .

According to [4] the Snowball Throwing learning model trains students to be more responsive in receiving messages from other people, and deliver the message to their friends in one group. Throwing questions does not use sticks like the Talking Stick learning model but uses paper containing questions that are kneaded into a paper ball and then thrown to other students. The student who gets the paper ball then opens and answers the question.

The self check is also referred to as a self-check style as [5] the definition of the characteristics of a self-check style is doing the task and is involved in self-evaluation guided by the teacher given certain criteria In the anatomy of the self-check style, the teacher's role is to make all Important subjects, criteria and decisions. The role of students is to work freely (alone) and to check their own performance against the criteria set by teacher. When this behavior is achieved, the following objectives are achieved.

According to [6] self-confidence is a person's belief to be able to behave in accordance with their hopes and desires. Confidence is also defined as a positive attitude of an individual that enables him to develop positive assessments, both towards oneself and the environment / situation it faces.
Confidence is also called self-esteem or self-image [7] is a comprehensive evaluative dimension of self.

According to [8] learning outcomes are abilities possessed by students after receiving a learning experience. The results of learning activities are characterized by changes in behavior toward a relatively permanent positive in the person who learns. In connection with that opinion, [9] explains that someone can be said to have succeeded in learning if he is able to show a change in him. These changes include aspects of thinking ability, skills, or attitude towards an object.

From the expert's explanation above it can be said that without confidence in learning, it will affect in achieving learning outcomes. This means that in achieving good learning outcomes, confidence is needed. The impact of precisely the confidence given, the success in learning will be better (optimal).

\section{RESEARCH METHODS}

This research was conducted at Bandar Setia Private Middle School in the academic year 2018/2019. Implementation of treatment (treatment), [10] states that the exercise carried out 6-8 weeks will have sufficient effect with a strength of $10-25 \%$. El Fox quoted states that whether to use frequency 3 or 5 times a week, but what is important is the 4-8 week duration of exercise.

The method used in this study is the experimental method, because it does not take random samples but intact samples to be treated, the experiment itself is an observation under artificial conditions where the conditions were made and arranged by the researcher with a $2 \times 2$ factorial design according to [11], with a total sample of 30 students.

\begin{tabular}{|l|l|l|}
\hline $\begin{array}{l}\text { Model Pembelajaran } \\
(\mathrm{A})\end{array}$ & $\begin{array}{l}\text { Example } \\
\text { Non }\end{array}$ & $\begin{array}{l}\text { Picture } \\
\text { And } \\
\text { Picture } \\
\left(\mathrm{A}_{2}\right)\end{array}$ \\
\hline $\begin{array}{l}\text { Motivasi Belajar } \\
(\mathrm{B})\end{array}$ & $\begin{array}{l}\text { Ext+xple } \\
\left(\mathrm{A}_{1}\right)\end{array}$ & 12 \\
\hline Tinggi $\left(\mathrm{B}_{1}\right)$ & 12 & 12 \\
\hline Rendah $\left(\mathrm{B}_{2}\right)$ & 12 & 24 \\
\hline Total & 24 & \\
\hline
\end{tabular}

To facilitate the control of each treatment group the research design is as follows:

TABLE 1. RESEARCH DESIGN

\begin{tabular}{|c|c|c|}
\hline \multirow{2}{*}{$\begin{array}{l}\text { 1. Sikap } \\
\text { kepercaya } \\
\text { an diri } \\
\text { (B) }\end{array}$} & \multicolumn{2}{|c|}{$\begin{array}{l}\text { Model } \\
\text { pembelajaran }(\mathrm{A})\end{array}$} \\
\hline & $\begin{array}{l}\text { Snowball } \\
\text { Throwing } \\
\text { (1) }\end{array}$ & $\begin{array}{l}\text { Periksa } \\
\text { Diri } \\
(2)\end{array}$ \\
\hline $\begin{array}{l}\text { Kelompok Tinggi } \\
\left(\mathrm{B}_{1}\right)\end{array}$ & $\mathrm{A}_{1} \mathrm{~B}_{1}$ & $\mathrm{~A}_{2} \mathrm{~B}_{1}$ \\
\hline $\begin{array}{l}\text { Kelompok Rendah } \\
\left(\mathrm{B}_{2}\right)\end{array}$ & $\mathrm{A}_{1} \mathrm{~B}_{2}$ & $\mathrm{~A}_{2} \mathrm{~B}_{2}$ \\
\hline Rata-rata & $\mu_{\mathrm{A} 1}$ & $\mu_{\mathrm{A} 2}$ \\
\hline
\end{tabular}

Information :

A1B1 = Learning model that is taught by using the Snowball Throwing model for groups of students who have high self-confidence groups 
A1B2 = Learning model that is taught by using the Snowball Throwing model for groups of students who have low self-confidence groups

$\mathrm{A} 2 \mathrm{~B} 1$ = Learning model taught using the Self-Check learning model for groups of students who have high selfconfidence groups

A2B2 = Learning model taught using the Self-Check learning model for groups of students who have low selfconfidence groups

$\mu \mathrm{A} 1=$ Average learning model taught using Snowball Throwing learning

$\mu \mathrm{A} 2=$ The average learning model taught using Self Check learning

$\mu \mathrm{B} 1=$ The average learning model taught that has an attitude of high group trust

$\mu \mathrm{B} 2=$ The average learning model taught that has low self-confidence groups

\section{A. Validity Of Content}

The validity of motivational instrument items, in the form of face validity using experts, which will be consulted with two experts in their fields. How to investigate the validity of the contents of physical education measurement tools can be done by using the opinion of a 'panel' consisting of experts in the field of physical education and experts in measurement. If the material of the measuring instrument matches the material for the preparation of the measuring instrument, it means that the measuring instrument has content validity [12]. Validity test is carried out with the aim of knowing the extent to which the test can measure the exact aspects to be measured. Based on this, the validity test of this test is to use the expert justification test, where the instruments have been prepared

consulted with 2 experts (experts).

\begin{tabular}{|c|c|c|}
\hline No. & Nama & Jabatan \\
\hline 1. & $\begin{array}{l}\text { Dr. Imran } \\
\text { Akhmad, M. Pd } \\
\text { NIP.19730904 } \\
1999031002\end{array}$ & Ahli 1 \\
\hline 2. & $\begin{array}{l}\text { Dr. } \quad \text { Rahma } \\
\text { Dewi, M.Pd. } \\
\text { NIP. } 19701101 \\
\text { 199601 } 2001\end{array}$ & Ahli 2 \\
\hline
\end{tabular}

\section{B. Reability}

Reliability of research instruments using a retest (test-retest). The validity of the instrument results from learning motivation, in the form of surface validity (face validity). Reliability of research instruments using a retest (test-retest). In this case the formula used to determine the level of reliability of a test used the formula of product moment correlation numbers rough (Arikunto, 2009: 72), namely:

r_xy $=($ NJI YXY $-(J I X)(\mathcal{\& I})) / \sqrt{ }\left(\left\{\mathrm{NJI} \wedge \mathrm{X}^{\wedge} 2-(\mathcal{\beta} \mathrm{X})^{\wedge} 2\right\}\right.$ $\{\mathrm{NJI} \wedge \wedge 2-(\mathcal{Q Y}) \wedge 2\})$
Where:

r_xy: Correlation between variables $\mathrm{X}$ and $\mathrm{Y}$

$\mathrm{N}$ : Number of samples

$\mathrm{X}$ : Score of each item

Y: Total score

\section{DATA ANALYSIS TECHNIQUE}

Data analysis technique used the two-way Analysis of Variance (ANAVA) technique, and was followed by further tests of Gene Kenneth (1984: 417) using the Tukey Test, with a confidence level $\alpha=0.05$. Before the data was used using analysis of variance (ANAVA) ANAVA test was performed, namely the Normality Test using the Kolmogorov Smirnov Test, and the Variance Homogeneity Test using the F-Test, with a confidence level $\alpha=0.05$ [13].

Normality test

The normality test used is the Kolmogorov-Smirnov test carried out with the following steps:

Hypothesis formulation

H0: Samples come from normally distributed populations

H1: Samples come from populations that are not normally distributed

Data is sorted from smallest to largest

Determine the cumulative proportion $(\mathrm{kp})$

Data is transformed into standard scores:

Determine the zi curve area (z-table)

Determine a1 and a2

The absolute maximum values of a1 and a 2 are notated with Do

Determine the D-table price;

Testing criteria

If Do D-table then $\mathrm{H} 0$ is accepted

If Do> D-table then $\mathrm{H} 0$ is rejected

Conclusion

Do D-table; samples come from normally distributed populations

Do> D-table; samples come from populations that are not normally distributed. If it is not normally distributed, nonparametric statistical tests are required.

Homogeneity Test

Next for homogeneity test using the F-test, with the formula:

$\mathrm{F}_{-}$calculate $\left.=\wedge \mathrm{S}^{\wedge} 2\right) \_$large $/\left[\mathrm{S}^{\wedge} 2\right) \_$small, (Kadir, 2015: 162)

The test criteria are accept $\mathrm{H} 0$ if Fcount $<$ Ftable and reject $\mathrm{H} 0$ if you have other prices.

Statistic test

Calculating the Number of Squares (JK) for several sources of variance, namely Total $(\mathrm{T})$, the learning model factor is denoted by Antar (A), the learning motivation factor is denoted by Antar (B), the interaction between learning models with learning motivation is symbolized by Interaction (AB), and In (D), with the following formula:

$\mathrm{JK}(\mathrm{A})=\sum(\mathrm{i}=1)^{\wedge} \mathrm{a} \boldsymbol{\beta}\left(\mathcal{\beta} \_\mathrm{i}\right) \wedge 2 / \mathrm{n} \_\mathrm{i}-\left(\mathcal{H}_{-} \mathrm{t}\right)^{\wedge} 2 /$ n_t 


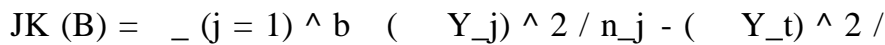
n_t

$\mathrm{JK}(\mathrm{AB})=\sum(\mathrm{j}=1, \mathrm{i}=1)^{\wedge} \mathrm{ab} \nLeftarrow\left[\left(\mathrm{Y}_{-} \mathrm{ij}\right)^{\wedge} 2 / \mathrm{n} \_\mathrm{ij}\right]-\left(\mathcal{\beta} \_\mathrm{t}\right)$ $\wedge 2$ / n_t - JK (A) -JK (B)

$\mathrm{JK}(\mathrm{D})=\sum(\mathrm{j}=1, \mathrm{i}=1)^{\wedge} \mathrm{ab} \otimes\left[\sum \mathrm{Y}_{-} \mathrm{ij}\right]^{\wedge} 2-\left(\mathrm{Y}_{-} \mathrm{ij}\right)^{\wedge} 2 /$ $\left.n \_i j\right]=\nLeftarrow \otimes\left(y \_i j\right) \wedge 2$

$\mathrm{JK}(\mathrm{T})=\boldsymbol{\beta}\left[\mathrm{Y}_{-} \mathrm{t}\right]^{\wedge} 2-\left(\boldsymbol{\beta} \_\mathrm{t}\right)^{\wedge} 2 / \mathrm{n} \_\mathrm{t}$

Determine the degree of freedom $(\mathrm{db})$ of each source of variance

$\mathrm{db}(\mathrm{A})=$ na -1 ,

$\mathrm{db}(\mathrm{B})=\mathrm{nb}-1$,

$\mathrm{db}(\mathrm{AB})=(\mathrm{na}-1)(\mathrm{nb}-1)$,

$\mathrm{db}(\mathrm{D})=\mathrm{nt}-(\mathrm{na})(\mathrm{nb})$, and

$\mathrm{db}(\mathrm{T})=\mathrm{nt}-1$

Determine Average Number of Squares (CPR)

1) $\cdot \operatorname{RJK}(\mathrm{A})=(\mathrm{JK}(\mathrm{A})) /(\mathrm{db}(\mathrm{A})) 2) \cdot \operatorname{RJK}(\mathrm{B})=(\mathrm{JK}(\mathrm{B})) /(\mathrm{db}$ (B))

3) $. J K(A B)=(J K(A B)) /(d b(A B)) 4) . J K(D)=(J K(D)) /$ (db (D))

Determine FO

(1) .F $] \_\mathrm{O}(\mathrm{A})=(\mathrm{CPR}(\mathrm{A})) /(\mathrm{CPR}(\mathrm{D}))\left[(2) . \mathrm{F} \rrbracket \_\mathrm{O}(\mathrm{B})=\right.$ (CPR (B)) / (CPR (D))

[3). F】_O (AB) $=(\mathrm{CPR}(\mathrm{AB})) /(\mathrm{CPR}(\mathrm{D}))$

\section{ANAVA table}

Table 2. Two Line Anava Table

Source of Variance JK Db RJK Observation Fable

$\alpha=0.05$

Between A JK (A) na - 1 RJK (A) F_O (A) = RJK (A) / RJK (D)

Between B JK (B) nb - 1 RJK (B) F_O (B) = RJK (B) / RJK (D)

Interaction of $\mathrm{AB} J K(\mathrm{AB})(\mathrm{na}-1)(\mathrm{nb}-1)$ RJK $(\mathrm{AB}) \mathrm{F} \_\mathrm{O}$ $(\mathrm{AB})=\mathrm{RJK}(\mathrm{AB}) / \mathrm{RJK}(\mathrm{D})$

In JK (D) nt - (na) (nb) RJK (D)

Total JK (N) nt - 1 - -

\section{DISCUSSION OF RESEARCH RESULTS}

Test criteria, if $\mathrm{FO}>\mathrm{F}$ table at the significant level chosen with the numerator $\mathrm{db}$ is the corresponding $\mathrm{db}$, then $\mathrm{H} 0$ is rejected, so it is concluded that there is a difference in average increase between the groups tested, in contrast to F_O $\mathrm{F}_{-}$tabel, then $\mathrm{H} 0$ is accepted

Based on the above explanation, the hypotheses in the discussion of this study are:

There is a difference between the snowball throwing learning model and the self-check learning model towards orthodox style shot put learning outcomes

There is an interaction between the snowball throwing learning model and the self-examination learning model of orthodox style shot put learning outcomes

Better between the snowball throwing learning model and the self-check learning model of orthodox style shot put on low self-confidence student groups

Better between the snowball throwing learning model and the self-check learning model towards orthodox bullet-proof learning outcomes in high confidence student groups

\section{References}

[1] Frank M. Verducci, Ed. D. 1980. Measurement Concepts in Physical Education. London: Mosby Company.

[2] Adang Suherman. 2000. Fundamentals of Physical Education. Jakarta: Ministry of Education and Culture Director General of Primary and Secondary Education.

[3] Adang Suherman, et al. 2001. Athletic Learning. Jakarta: Dirjendikti.

[4] Adang Suherman, Yudha Saputra, and Yudha Hendrayana. 2001. Athletic Learning Game \& Competition Approach for high school / vocational students. Jakarta Directorate General of Sports.

[5] Agus Suprijono. 2010. Cooperative Learning. Theory and Application of PAIKEM. Yogyakarta: Student Library.

[6] Didik Zafar Sidik. 2010. Teaching and Training Athletics. Bandung: PT Remaja Rosdakarya.

[7] Ega Trisna Rahayu. 2013. Physical Education Learning Strategies Implementation of Physical Education, Sports and Health Learning. Bandung: CV Alfabeta.

[8] Aip Syarifuddin. 1992 Athletics. Jakarta: Ministry of Education and Culture Dirjendikti.

[9] Aunurrahman. 2012, Learning and Learning. Bandung: CV Alfabeta.

[10] Bambang Hartono. 1994. Train Children Confidence. Jakarta: Gunung Mulia.

[11] Cheryl A. Coker, Motor Learning and Control for Practitioners. New York: McGraw-Hill, 2004.

[12] Dimyati and Mudjiono. 2009. Learning and Learning. Jakarta: PT Rineka Cipta.

[13] Hamdani. 2011. Teaching and Learning Strategies. Bandung: Loyal Reader. 